\title{
The effect of glucose infusion on the plasma free amino acids in sheep
}

\author{
By N. W. OFFER, M. V. TAS, R. F. E. AXFORD and R. A. EVANS \\ Department of Biochemistry and Soil Science, Memorial Buildings, Bangor, \\ Gwynedd LL $L_{57} 2 U W$, Wales
}

(Received 27 August 1974-Accepted 17 Fanuary.1975)

\begin{abstract}
I. Glucose in solution in saline, or saline alone, was administered to a group of twenty ewes during late pregnancy and again after lambing. Sequential blood samples were taken before and after the infusion and the concentration of plasma free amino acids was determined.

2. The effect of glucose was to reduce the concentrations of all amino acids except alanine. The reduction was greatest for tryptophan in the pregnant sheep, but this amino acid showed no significant change in the lactating animals.

3. An attempt to rank the amino acids on the basis of their response to glucose infusion indicated that, with the exception of tryptophan for the preparturient ewes, groups of essential amino acids could not be distinguished from each other. These groups were, for the preparturient sheep, valine, leucine, phenylalanine and isoleucine, and for the postparturient animals, isoleucine, lysine, methionine, valine and phenylalanine.
\end{abstract}

Recent interest in the control of nitrogen metabolism in the rumen (Hutton \& Annison, 1972) has drawn attention to the need for better definition of the amino acid requirements of ruminants (Armstrong \& Annison, I973).

It has been proposed that the amino acids limiting for growth in ruminant nutrition could be identified by studying changes in the plasma amino acid concentration after the infusion of an energy supplement (Potter, Purser \& Cline, I968). The present experiment was designed to test this hypothesis using a larger number of sheep than has been previously used, and at stages in their productive cycle when their protein requirements would be maximal. Glucose was chosen as the energy source as it was found by Potter et al. (r968) and by Eskeland, Pfander \& Preston (1974) to produce the greatest changes in the plasma concentrations of essential amino acids (EAA).

\section{EXPERIMENTAL}

Animals and diet. Twenty pregnant Welsh Mountain ewes were confined indoors with free access to good-quality meadow hay and water. Approximately 6 weeks before the expected lambing date this diet was supplemented with I $50 \mathrm{~g}$ compound nuts (Flockmaster nuts; RHM Agriculture Limited, Wimborne, Dorset)/d. The supplement was given at $\mathbf{2} 2 \mathrm{~h}$ intervals, in individual feeders. The level of supplementation was increased weekly according to the manufacturers' recommendation until a level of $35^{\circ} \mathrm{g} / \mathrm{d}$ was reached. The sheep were maintained on this ration for a period of $6 \mathrm{~d}$ during which the average intake of hay was $\mathrm{I} \cdot 2 \mathrm{~kg} / \mathrm{sheep}$ per $\mathrm{d}$.

Experimental procedure. For the next $3 \mathrm{~d}$ the daily intake was limited to $300 \mathrm{~g}$ nuts and $600 \mathrm{~g}$ hay per animal, providing approximately $100 \mathrm{~g}$ crude protein $(\mathrm{N} \times 6 \cdot 25)$. This limited the energy intake in order to increase the likelihood of response to intra- 
venous administration of an energy source. On the next day, $\mathrm{I} h$ after it had received its morning feed, each sheep was fitted with a Polythene catheter in one jugular vein. After $\mathrm{I} h$ and then after $30 \mathrm{~min}$ intervals, $5 \mathrm{ml}$ blood samples were taken from each sheep through the catheter. The samples were collected into precooled, heparinized polyethylene centrifuge tubes which were immediately centrifuged. Plasma samples $(3 \mathrm{ml})$ were pipetted into sample bottles each containing $0.15 \mu \mathrm{mol}$ norleucine (internal standard for amino acid analysis). These bottles were frozen at once and stored at $-20^{\circ}$ until analysed.

After the fifth sample had been taken, each sheep received an infusion into the jugular cannula, of either glucose solution $(500 \mathrm{~g} / 1)$ in isotonic saline $(9 \mathrm{~g} \mathrm{NaCl} / 1)$ (sixteen sheep) or isotonic saline (four sheep), the dose was $\mathrm{I} \mathrm{ml} / \mathrm{kg}$ live weight. Allocation to the treatments was randomized. Five further blood samples were then collected from each sheep at $30 \mathrm{~min}$ intervals, as described previously.

After the experimental procedure the flock returned to its full daily ration of $35^{\circ} \mathrm{g}$ nuts plus hay ad lib. Lambing followed over the next $39 \mathrm{~d}$ (mean $23 \pm 2.3 \mathrm{~d}$ ). At io d after the last lamb was born the infusion procedure was repeated, when the ewes were on average $26 \mathrm{~d}$ post partum.

Analytical procedure. The plasma samples were deproteinized by centrifugal filtration through micropore filters (Amicon membrane cones; Amicon Corp., Lexington, Mass. 02173, USA) because acidic precipitants have been found to cause significant losses of tryptophan (Stephens, 1973). Plasma free amino acid concentrations were determined by automated amino acid analysis (Thomas, 1970). This method does not resolve glutamine and asparagine from threonine (Stephens, 1973). In the quoted results, threonine values therefore include unquantified contributions from these compounds. Since measurement of extinction of the ninhydrin-reaction product was made only at $570 \mathrm{~nm}$, the accuracy of proline determinations was low and the values are not included.

Glucose concentration was determined for each plasma sample by the method of Morley, Dawson \& Marks (1968).

\section{RESULTS}

The changes in plasma glucose concentration for each group of sheep in each experiment are shown in Fig. I. The infusion of glucose in saline caused a large increase in the plasma glucose concentration in the experimental sheep both before and after parturition; for sheep given saline infusion, glucose concentrations were unchanged. Also shown in Fig. I are the values for concentrations of total EAA and total non-essential amino acids (NEAA) in the plasma. For samples taken before the infusions the mean plasma concentrations for EAA and NEAA $(\mathrm{mg} / \mathrm{l})$ were $9 \mathrm{I}$ and $\mathrm{x} 7 \mathrm{O}$ for preparturient sheep, and 86 and ${ }_{1} 73$ for postparturient sheep with a markedly greater stability for the EAA than NEAA. After infusion with saline, the concentrations of EAA and NEAA for the preparturient animals showed an increase but those for the postparturient animals were not affected. Glucose infusion resulted in significantly lower concentrations of both groups of amino acids than did the saline infusion.

An analysis of variance of the concentrations of individual amino acids showed no 

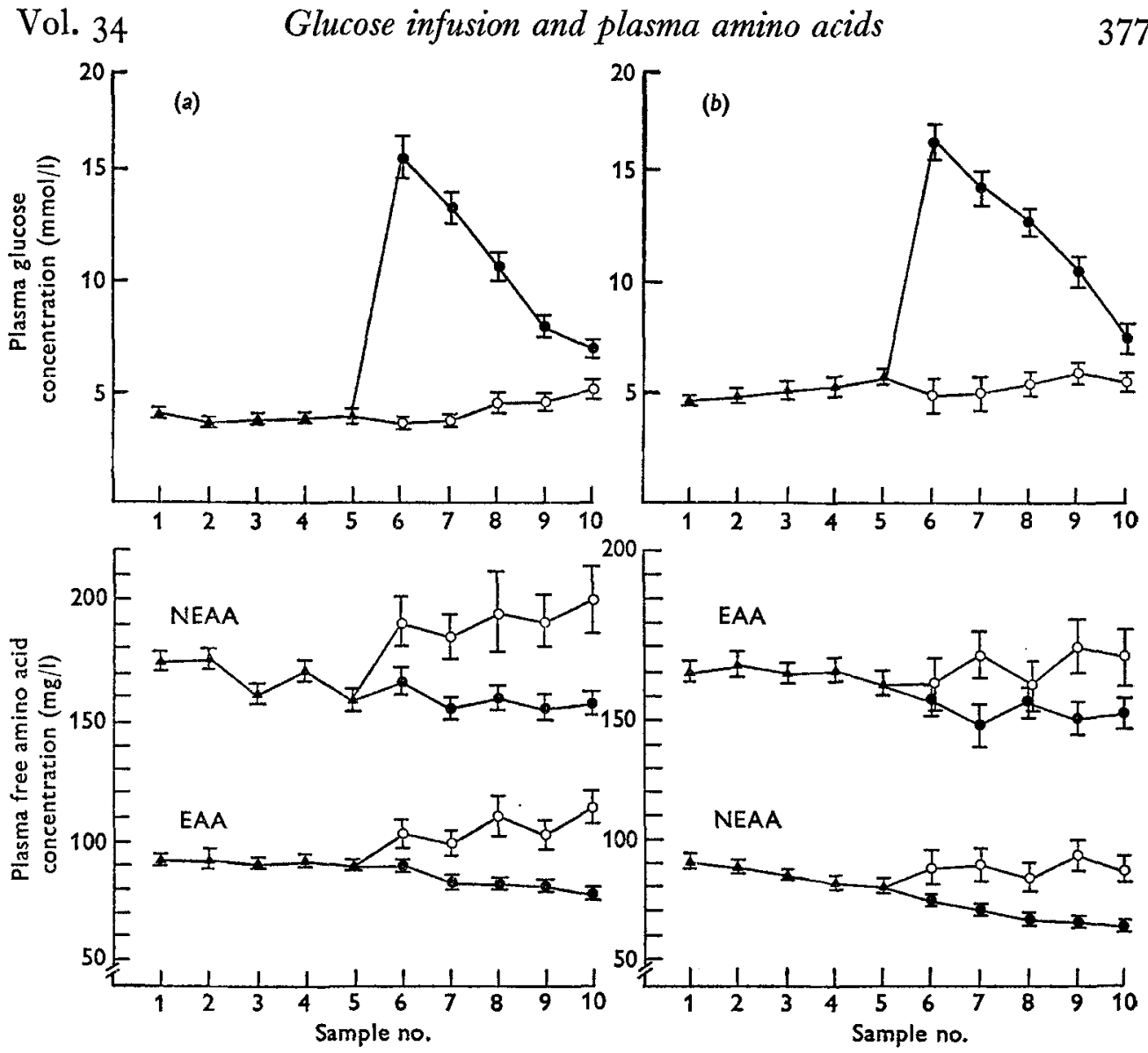

Fig. I. Changes in plasma glucose, total non-essential amino acids (NEAA) and total essential amino acids (EAA) in $(a)$ pre- and $(b)$ postparturient ewes before $(\boldsymbol{\Delta}-\boldsymbol{\Delta})$ and after infusion of either isotonic saline $(9 \mathrm{~g} \mathrm{NaCl} / 1)(\mathrm{O}-\mathrm{O})$ or glucose in isotonic saline (500 $\mathrm{g} / \mathrm{l})$ (O- Plasma samples were obtained $2 \mathrm{~h}$ after the morning feed, then at $30 \mathrm{~min}$ intervals. After the fifth sample the sheep were infused with I $\mathrm{ml}$ glucose solution (sixteen sheep) or saline (four sheep) $/ \mathrm{kg}$ live weight and plasma samples were taken at 30 min intervals after infusion. The points are mean values with their standard errors represented by vertical bars.

trend in the five sequential samples taken before infusion. The mean values for the five samples for each sheep were used in subsequent calculations. Table I gives the mean concentrations of amino acids for plasma samples I-5 (pre-infusion). Significantly $(P<0.05)$ higher values for glutamic acid and tryptophan were found in postparturient sheep, with significantly lower values for aspartic acid, threonine ( + amides) and tyrosine. The concentrations of the other amino acids were unchanged.

The post-infusion plasma amino acid concentrations were determined and are given in Table 2 as plasma amino acid indices (PAAI) (mean post-infusion plasma amino acid concentration $\div$ mean pre-infusion plasma amino acid concentration $\times 100$ ) (Potter et al. 1968). Analysis of variance of the results indicated that stable levels of plasma amino acid concentrations after the infusion had not been reached for some amino acids by the time the sixth sample was taken. The PAAIs were therefore calculated using the mean value for samples 7 -Io which showed no time dependence. 
Table I. Pre-infusion plasma amino acid concentrations (mmol/l) for twenty pre-and postparturient sheep fitted with a jugular catheter I $h$ after their morning feed and sampled at $\mathrm{I} h$ and then at 30 min intervals after catheterization

\begin{tabular}{lccc}
\multicolumn{4}{c}{ (Mean values with their standard errors of mean values for twenty sh } \\
each based on five samples/sheep) \\
Amino acid & Preparturient & Postparturient & SE \\
Aspartic acid & 0.220 & 0.076 & $0.010^{*}$ \\
Threoninet & 0.116 & 0.064 & $0.005^{*}$ \\
Serine & 0.106 & 0.113 & 0.008 \\
Glutamic acid & 0.220 & 0.346 & $0.010^{*}$ \\
Glycine & 0.626 & 0.688 & 0.036 \\
Alanine & 0.194 & 0.196 & 0.010 \\
Valine & 0.108 & 0.121 & 0.008 \\
Methionine & 0.021 & 0.018 & 0.002 \\
Isoleucine & 0.080 & 0.078 & 0.004 \\
Leucine & 0.076 & 0.087 & 0.004 \\
Tyrosine & 0.045 & 0.036 & $0.003^{*}$ \\
Phenylalanine & 0.038 & 0.037 & 0.002 \\
Histidine & 0.120 & 0.115 & 0.006 \\
Tryptophan & 0.005 & 0.011 & $0.001^{*}$ \\
Lysine & 0.104 & 0.092 & 0.005 \\
Arginine & 0.130 & 0.123 & 0.006
\end{tabular}

* Mean values for postparturient sheep were significantly different from those for preparturien sheep: $P<0.05$.

+ Includes glutamine and asparagine.

\section{DISCUSSION}

We have been unable to find values reported in the literature comparing the plasma amino acid concentrations for pre- and postparturient ewes. We found significant differences, as indicated in Table $\mathrm{I}$ for aspartic acid, threonine, glutamic acid, tyrosine and tryptophan. In general the concentrations found are similar to those reported by other workers for growing lambs (e.g. Purser, Klopfenstein \& Cline, r966; Schelling, Hinds \& Hatfield, I967).

Saline infusion into the preparturient sheep caused a general and significant increase in the plasma amino acid concentrations. This effect was also indicated in the results reported by Potter et al. ( 1968 ) for sheep infused $6 \mathrm{~h}$ after feeding. This increase was not found in our lactating animals. It could have been due to the greater stress effect of bleeding on the pregnant animals which had been housed for only 5 weeks as compared with the lactating sheep which had been indoors for ro weeks and had already experienced the experimental procedure.

The glucose dose was chosen to be sufficient to maintain an increased plasma glucose level throughout the post-infusion sampling period.

Glucose infusion caused a reduction in the plasma amino acid concentrations for all the amino acids measured, except alanine, as compared with the saline-infused control animals; alanine concentrations increased. This agrees with the findings of Eskeland et al. (1974) and gives support to the central role of alanine in gluconeogenesis postulated by Cahill (1970). The administration of glucose would be expected to reduce the need for amino acid-derived gluconeogenesis in the liver, and thereby 
Vol. 34

Glucose infusion and plasma amino acids

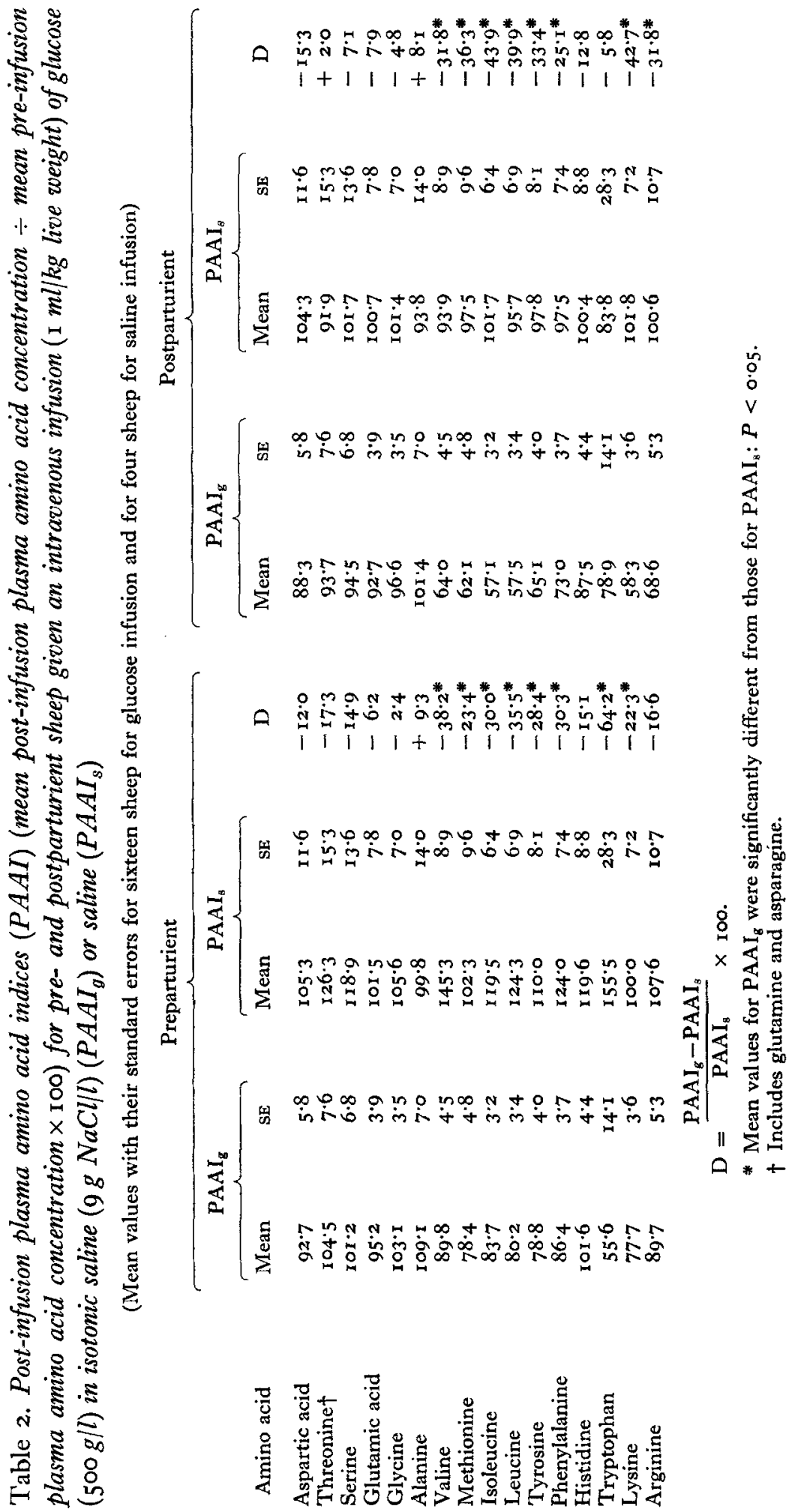


Table 3. A comparison of results obtained in the present experiment for ewes, and those of other workers using lambs, for reductions in plasma amino acid concentrations in sheep following glucose infusion

(Plasma amino acids have been placed in decreasing order of the percentage reduction resulting from glucose infusion)

Eskeland, Pfander \& Preston (1974)

\begin{tabular}{|c|c|}
\hline \multicolumn{2}{|c|}{ Present experiment } \\
\hline Preparturient & Postparturient \\
\hline Tryptophan & Isoleucine \\
\hline Valine & Lysine \\
\hline Leucine & Leucine \\
\hline Phenylalanine & Methionine \\
\hline Isoleucine & Valine \\
\hline Methionine & Phenylalanine \\
\hline Lysine & Histidine \\
\hline
\end{tabular}

\begin{tabular}{|c|c|}
\hline $\begin{array}{l}\text { High- } \\
\text { concentrate } \\
\text { diet }\end{array}$ & $\begin{array}{l}\text { High- } \\
\text { roughage diet }\end{array}$ \\
\hline Methionine & Isoleucine \\
\hline Isoleucine & Methionine \\
\hline Leucine & Leucine \\
\hline Valine & Arginine \\
\hline Phenylalanine & Lysine \\
\hline Lysine & Valine \\
\hline Arginine & Phenylalanine \\
\hline
\end{tabular}

Potter, Purser \& Kline (r968)

$\begin{array}{ll}6 \mathrm{~h} & 24 \mathrm{~h} \\ \text { post-feeding } & \text { post-feeding } \\ \text { Isoleucine } & \text { Isoleucine } \\ \text { Valine } & \text { Leucine } \\ \text { Leucine } & \text { Histidine } \\ \text { Threonine } & \text { Threonine } \\ \text { Lysine } & \text { Methionine } \\ \text { Histidine } & \text { Lysine } \\ \text { Methionine } & \text { Phenylalanine }\end{array}$

exert a sparing action on circulating alanine acting as a carrier for the transfer of glucogenic precursor from muscle to liver.

The reductions in the concentrations of plasma EAA following glucose infusion were greater than for NEAA. This presumably resulted from the ability of the animal to replace the latter group by metabolic transformations. The method of using the PAAIs to indicate limiting amino acids depends upon the assumption that the decrease in plasma amino acid concentration resulting from glucose infusion is related to the adequacy of amino acid supply to the animal. The proposed mechanism (Potter, Purser \& Bergen, 1972) is that glucose depletes the plasma free amino acids by promoting cellular uptake of amino acids with or without protein synthesis. The limiting amino acid would suffer the greatest proportional reduction in concentration and would therefore have the lowest PAAI value.

The only direct evidence in favour of the method is from experiments carried out in man (Munro \& Thompson, I953; Crofford, Felts \& Lacy, I964; Swendseid, Tuttle, Drenick, Jones \& Massey, I967). Potter et al. (1972), however, found in rats given eight diets that the lowest PAAI value obtained after glucose infusion did not correspond with the known limiting amino acids of the diets. These workers also infused various proteins, selected to have different limiting amino acids for simple-stomached animals, into the duodenums of sheep. The PAAI method failed to identify the amino acids assumed to be limiting. Eskeland et al. (1974) found a close relationship between reductions in plasma EAA, caused by intravenous infusions of various energy sources, and $N$ retention by the sheep. They suggested that this indicated that the plasma EAA were removed for protein synthesis after the energy infusion.

The results of the present work suggest that in the preparturient ewe plasma tryptophan concentration undergoes the greatest percentage reduction after glucose infusion. The next greatest reduction was in the concentrations of the group containing valine, leucine, phenylalanine and isoleucine, which were all reduced by a similar proportion. 
In the postparturient animal there was no significant change in plasma tryptophan concentration. The order of reduction in plasma concentration was isoleucine, lysine, methionine, valine and phenylalanine, with no significant difference between them.

Table 3 compares our results with those of other workers who have used the same method. An important distinction between the results is our inclusion of tryptophan which is known to be important in the control of protein synthesis (Munro, 1968). The order in which the plasma amino acid concentrations were reduced varied for the different experiments, although the differences between the amino acids which determined that order were mostly not statistically significant. This variation may be ascribed to differences in the physiological status of the test animals, and the various diets they were given. By attributing a numerical score to the ranking order of amino acids from each set of experiments it is possible to list the four most prominent as isoleucine, methionine, valine and lysine, in that order.

In the present experiment, with the exception of tryptophan, the method failed to isolate clearly a single limiting amino acid. This suggested that either no single amino acid was markedly more deficient than any other, or that the procedure as described was not sufficiently sensitive to identify it. There is evidence from other types of experiment to support the former explanation. Schelling \& Hatfield (1968) found that, for lambs, no single EAA when infused post-ruminally greatly improved $\mathrm{N}$ retention. Similarly, Hall, Hatfield \& Owens (1974) were unable to find a significant improvement of $\mathrm{N}$ retention in calves as a result of intraperitoneal infusions of single EAA. Both groups of workers did, however, find dramatic increases in $\mathrm{N}$ retention when groups of EAA were infused. Furthermore, unlike Wakeling, Lewis \& Annison (1970), Hall et al. (1974) were unable to detect a 'break point' in any of the plots of plasma amino acid concentration for a single EAA $v$. rate of infusion.

The results of our experiment suggested that tryptophan may have been limiting for the preparturient sheep. The postparturient animals, however, showed a similar response to that described by Fenderson \& Bergen (1972) for mature wethers: there was no significant reduction in plasma tryptophan concentration after glucose infusion. It is difficult to assess the significance of the response found for the preparturient sheep. No information exists on the requirement for tryptophan of the ewe in late pregnancy and there is little information about the availability of tryptophan in the sheep.

On the basis of our experiment we are unable to recommend the use of the PAAI method for the detection of limiting amino acids in the sheep. Until the results obtained by the method can be compared with the metabolic requirements for amino acids, independently determined, we are unable to assess whether those amino acids of lowest PAAI are in fact limiting.

The authors thank the Lord Rank Research Centre, High Wycombe, Bucks., for financial support for this work. N.W.O. is the recipient of a Rank Postdoctoral Fellowship. 


\section{REFERENCES}

Armstrong, D. G. \& Annison, E. F. (1973). Proc. Nutr. Soc. 32, 107.

Cahill, G. F. (1970). New Engl. F. Med. 282, 668.

Crofford, O. B., Felts, P. W. \& Lacy, W. W. (1964). Proc. Soc. exp. Biol. Med. II7, I I.

Eskeland, B., Pfander, W. H. \& Preston, R. L. (1974). Br. F. Nutr. 3r, 201.

Fenderson, C. L. \& Bergen, W. G. (1972). F. Anim. Sci. 35, 896.

Hall, G. A. B., Hatfield, E. E. \& Owens, F. N. (1974). F. Anim. Sci. 38, 124.

Hutton, K. \& Annison, E. F. (1972). Proc. Nutr. Soc. 31, 15 I.

Morley, G., Dawson, A. \& Marks, V. (1968). Proc. Ass, clin. Biochem. 5, 42.

Munro, H. N. (I g68). Fedn Proc. Fedn Am. Socs exp. Biol. 27, 123 I.

Munro, H. N. \& Thompson, N. S. T. (I953). Metabolism 2, 354.

Potter, E. L., Purser, D. B. \& Bergen, W. G. (1972). F. Anim. Sci. 34, 660.

Potter, E. L., Purser, D. B. \& Cline, J. H. (I968). F. Nutr. 95, 655.

Purser, D. B., Klopfenstein, T. J. \& Cline, J. H. (r966). F. Nutr. 89, 226.

Schelling, G. T. \& Hatfield, E. E. (1968). ₹. Nutr. 96, 3 I9.

Schelling, G. T., Hinds, F. C. \& Hatfield, E. E. (I967). F. Nutr. 92, 339.

Stephens, A. G. (1973). Studies on the utilization of amino acids in chicks. PhD Thesis, University of Wales.

Swendseid, M. E., Tuttle, S. C., Drenick, E. J., Jones, C. B. \& Massey, F. J. (1967). Am. F. clin. Nutr. 20, 243 .

Thomas, A. J. (1970). Automation, Mechanisation and Data Handling in Microbiology, p. 107. London: Academic Press.

Wakeling, A. E., Lewis, D. \& Annison, E. F. (1970). Proc. Nutr. Soc. 29, 60A. 